\title{
Islamic Counselling Model to Increase Religious Commitment (Study of Students at the University UIN Bandung)
}

\author{
Fenti Hikmawati ${ }^{1}$ \\ ${ }^{1}$ State Islamic University Sunan Gunung Djati Bandung \\ E-Mail: fentihikmawati@yahoo.com
}

\begin{abstract}
The study aims to test the effectiveness of Islamic counseling model for helping the students to tight their religious commitment. The religious commitment is covered in three major Islamic teachings: Iman (faith), Islam (surrender to Allah), and Ihsan (state of being observed by Allah). The model of Islamic counseling aims to tight students' religious commitment must to be applied immediately because the preface study reveals some students' religious commitment were not strong enough, their behavior and thinking symptoms tend to not appropriate yet with Islam norm among their association and conception toward the truth of God. To achieve the aim, the study was carried out with three steps: (1) designing a model of counseling; (2) trying out field study, using pretest-post test control group experimental design with 140 students of Islamic Religion Education, the Faculty of Tarbiyah and Teaching, State Islamic University, Sunan Gunung Djati, Bandung. Of 140 students, 70 students are from the classes: A (32 people), B (38 people), involved in control group and the test; 37 people from class $C$, and 33 students from class $D$ involved in the experiment group, and; (3) designing a final model by revising the model tried-out. The variable involved three major Islamic dimensions: the iman, Islam, and ihsan of the students. The model was designed based on the theory put forward by Musfir bin Said Az-Zalmmi, that is, an integrated counseling model. The model combines and employs the ideas from other concepts into a tightly united concept, called Islamic concept. Upon completing analysis, it was found that the new concept is significantly effective to enhance students' religious commitment. A Model of Islamic Counseling (MIC) is an alternative-counseling model that can be employed for teenagers/ students to enhance their religious commitment. The study recommends that: (1) MIC can be applied to fifth semester students in the Faculty of Tarbiyah State Islamic University; (2) the application of MIC collaborates with professional and proportional elements relevant to the expected aim; (3) the researchers studying the same materials use the appropriate method appropriate to individual characteristics referring to Islamic norms kaffah (integrally).
\end{abstract}

Keywords: Islamic Counseling Model and Religious Commitment

\section{A. INTRODUCTION}

The presence of religious education as a foundation of learning process in State Islam University Bandung environment is expected that students able to have religious commitment because it is an important thing for their activities both inside and outside the campus.

Based on preliminary study of religious commitment on some students were low, there were behaviors to be not in accordance with Islamic norms, such expressions some students experience in writing report, namely: they were not convinced enough of Islam as religion because they have not understood Islam as a whole, cannot repent until now causing more and more to sin, difficult to be stay in istiqomah, difficult to always do good in whatever circumstances, and any behaviors not in accordance with Islamic Sharia. 
Based on these facts, it can happen because of how accepting and responding to religious education different from what was supposed to be. Truly by applying the religion would be able to resolve shock and imbalance that occurred in the community (Daradjat, 1993: 118). Shock feelings happened to students could be caused by the conflict and disharmony in the family, society, and campus environment. Students' anxiety caused by the moral values taught by religion was different from the behaviors that occurred in public environments. Therefore in a religious building on the student, educators/ counselors must be able to explore the students' soul so that they could be led, guided, and could be directed to understanding the true religion so that in counseling process could appease their soul from the soul shock while.

To complete the achievement of religious commitment, students should: (a) Find the answer to the question "Who am I?", (B) Determining the future orientation and answer the question "Where are my goals?", And (c) "what would be am I?" if students failed in their searching for religious identity (religious commitment), then the student will experience self doubt, confusion roles, and satisfied with the fixation, and doing the destructive themselves activities. One of commitment determinations in an effort to increase religious commitment towards the higher level is a willingness to understand and apply religious values (Islam) in everyday life, which includes faith, Islam and goodness (Ansari, 1983, p.31).

The researchers considered to help students to improve religious commitment is using interventions that focus on students, especially in behavioral psychology cognitive in accordance with Islamic guidance counseling principles, which emphasizes the notion that the changes should be based on the student's own desire / start from the self (ibda binafsik) with the syar'i (Islam) based. The model that was applied in this study was Islamic counseling model, which was expected to increase students' religious commitment.

Basic model of Islamic counseling in the writing of this dissertation is al-Quran as the first and the foremost guidance for Muslims, then the implementation process have: (1) Clear basis (2) Clarity of purpose to be achieved. (3) Clear procedures / process. (4) No doubt it (the Qur'an). (5) Instructions for those who fear Allah. (6) (Al Furqan) a clear distinction between right and falsehood. (/) Attempting to deliver to the benefit of life (mashalihu al-lbad / a rahmatan lil alamin) for the universe.

Islamic Conseling Model is expected to: (1) Putting the "al-Qur'an" as a basis to resolve various problems of life, so it can maintain religious commitment to students' self as "the noblest creature of God" (khalifatullah fil ardl). (2) Study the Qur'an in a "proper and right", so the Qur'an is used to find the benefit of life (mashalihu al-lbad). (Hanifah, 1989: ii). (3) Being a mukmin (someone who has a conviction) which is not only manifested by words and belief in the heart. More than that, faith is the manifestation of acts based on spiritual reflection to encourage people to love and obey the laws of Allah and His Messenger, more than anything about all aspects of life (Hadi, 1981: 7). (4) Having a religious commitment (sense of self tied) toward Islam which is manifested by: (a) believe in Islam. (b) Knowing the guidance of Islam. (c) Applying Islam. (d) Invite people to Islam. (e) Patient in to Islam, Then by Islamic Counseling able to carry moral responsibility and i'tiqadi "Ana Muslimun qabla kulli Syaiin" (prior to any action, I realized that I was a Muslim". (Ansari, 1983, p. 77).

This research led to be formed Islamic Counseling Model (ICM) as an effective way in helping students to develop the dimensions of faith, Islam and charity as the estuary of religious commitment. 


\section{B. METHODOLOGY}

A research method used was quasi-experimental method (Campbell \& Stanley, 1966; Cozby, 1989; Gay, L.R, 1987; Juckman, 1978; \& Montgomer, 1984, p.189). Hypothesis study testing conducted with quasi-experimental design "group pre test-post test design" (Krathwohl, David R, 1993). The groups involved are treated group called the experimental group abbreviated EG and groups who are not given the treatment used as the comparison group called the controlled group abbreviated CG. Treatment "vas given to the experimental group (EG) performed one time for one semester. Therefore this design is called "one-shot pre test/post test sign" (Heppner, PP, et al, 1992, p. 52-53).

Experimental design can be seen in Figure 3.1 below:

Figure 3.1 Experimental design

Explanation: $\mathrm{R}$ indicates the selection classes sample; $\mathrm{O}$ shows measurement (test):
$\mathrm{O} 1$ and $\mathrm{O}$ 2 are pre test, $\mathrm{O}$ and $\mathrm{O}$ 4 are post test; and the $\mathrm{X}$ indicates the treatment.

\section{Stage Research}

The study was conducted in three phases of activity (1) collecting data before the experiment, (2) The implementation of experiments, and (3) The collection of data after the experiment, these steps were as follows: (a). Researcher was introduced as a lecture of guidance and counselling and a counsellor on campus before the research conducted, (b) data of all students who become the subject of research collected before the experiment (pre-test), both the control group data and experimental group data. Tester was researcher in the regular classroom scene in guidance counselling courses, (c). Implementation of experiments conducted on a semester 2007/2008 academic years, each classroom experiments treated at lea.st two times a week. (d). Then, two weeks before the midterm test of 2007/2008 academic year, test conducted after treatment carried out.

Based on the overall activities of the preparation of the model, then the research stages are as follows:

\section{a. Preliminary Study}

In a preliminary study conducted two activities those were literature review and empirical study. Literature review carried out in order to obtain information about the theory of religious commitment, Islamic counselling, and Islamic counselling model by reviewing the various books, journals, research reports, and sources of other readings relating to the theory of religious commitment, Islamic counselling, and the model of Islamic counselling.

Empirical studies carried out by using descriptive research design in order to obtain data about the profile of students' religious commitment and the service to student in improving of religious commitment. 


\section{b. The design of hypothetical Islamic counselling model}

Based on the results of preliminary studies above, then arranged hypothetical Islamic counselling model to improve students' religious commitment in state Islam University. In the arrangement of counselling model researchers discussed with several professors of Islamic Education and consulted with the supervisor so that the resulting model is feasible theoretically to improve to students' religious commitment services.

Hypothetical model of Islamic counselling generated several components consists of rational, the vision, mission, purpose, functions and roles of counsellor, materials, counsellor requirements, procedures, strategies, and evaluation and implementation of guidelines summarized in UICSA (Unit of Islamic Counselling Services Agenda).

\section{c. Feasibility test of hypothetical Islamic Counselling model}

This activity is intended to get input counselling and religion expert on the feasibility of hypothetical Islamic counselling model for the improvement of students' religious commitment in State Islam Bandung University. This activity was carried out through seminars, but the implementation of the seminar was not done at one place and the same time, but done by sending the text "Islamic Counselling model to Increase Religious Commitment" to experts who had the time and place previously determined, then the time been agreed (between one to two weeks) the researcher met with the experts to get their input. This method adopted for consideration (a) because it is not easy to meet with the experts at the place and the same time, (b) to allow the experts reviewing the manuscript and gave input and (c) so that researchers can discuss and clarify the input of the experts as personally.

\section{d. Revision of hypothetical Islamic Counselling model}

Inputs from the previous seminar used to revise the model of counselling. During revising of counselling model, researchers continue to consult with the supervisor to obtain further input in order that the counselling model, which had been generated, had an effective standard to be applied in the service of improving students' religious commitment in State Islam University Sunan Gunung Djati Bandung.

\section{e. Field Test}

Based on the result of revision in the hypothetical model, the field test was conducted to determine the effectiveness of the hypothetical Islamic counselling model. The effectiveness test of the model experiment was carried out through the application of Islamic counselling model for improving students' religious commitment in State Islam University by using quasi-experimental design (Campbell \& Stanley, 1966; Cozby, 1989; Gay, LR, 1987; Juckman, 1978; \& Montgomer, 1984: 189). To test the hypothesis of the study used a quasi-experimental design "group pre test post test design" (Krathwohl, David R., 1993). The groups involved are treated group (called the experimental group abbreviated EG) and the group not given the treatment. The not treated group used as the comparison group (called the control group abbreviated CG). Treatment was applied to experimental group (EG) performed one time for one semester. Therefore, this design is called "one-shot pre test I post test sign" (Heppner, PP, et al, 1992: 52-53). The test was expected to obtain the findings about the effectiveness of counselling models for the improvement of Islamic religious commitment (aspects of the faith, Islam, and charity). 


\section{Subjects of Research}

These subjects of research were students of Islam Education, consist of two study groups taken from 8 classes (eight classes: A, B, C, D, E, F, G, and H) of the 2007/2008 school year in the faculty of Tarbiyah (education) State Islam University Sunan Gunung Djati Bandung. Two groups had been served as Experimental group (EG) and two other groups as controlled group (CG). Determination of Experimental Group and Control Group established by random technique toward regular classes of fifth semester consist of eight parallel classes. Random sampling was generated the class $C$ and $D$ as experimental group, while $A$ and $B$ as control group. Sampling results were presented in

Table 3.1:Subject of research

\begin{tabular}{|l|l|l|l|l|l|l|}
\hline & \multicolumn{5}{|l|}{ Experimental Group } & \multicolumn{4}{l|}{ Controlled group } \\
\hline Class & $\mathrm{C}$ & $\mathrm{D}$ & Number & $\mathrm{A}$ & $\mathrm{B}$ & Total \\
\hline Number & 37 & 33 & 70 & 32 & 38 & 70 \\
\hline
\end{tabular}

The characteristic samples were as follows: students ages 17-18 to 21-25, male / female Moslem. The reason foundation of subjects' selection of students aged such a like that was because of they are in period of trying to achieve the improvement and maturity of their religious beliefs (Az-Zahrani, 2005:397 and Daradjat, 1973: 91).

Research \& indicator variable size can be summarized in Table 3.2

\begin{tabular}{|l|l|l|}
\multicolumn{3}{|c|}{ Variable of Research: } \\
\hline Variable Name & Variable Types & Indicator \\
\hline Islamic Counseling model treatment & $\begin{array}{l}\text { Independent } \\
\text { (Intervention) }\end{array}$ & Islamic Cunseling Model \\
\hline Group & Independent & Grouping of Subject (CG and EG) \\
\hline Dimension of Faith, Islamic, and Charity & Bounded & $\begin{array}{l}\text { Combined scale: Scale of Faith, } \\
\text { Islamic, and Goodness }\end{array}$ \\
\hline Effectiveness of Islamic Counseling Model & $\begin{array}{l}\text { Bounded } \\
\text { (criterion) }\end{array}$ & $\begin{array}{l}\text { Gain (difference of scale between } \\
\text { post-test and pre-test) }\end{array}$ \\
\hline $\begin{array}{l}\text { Initial conditions (high-low pre-test scale } \\
\text { religious commitment) }\end{array}$ & Controlled & Scale of Faith, Islamic, and Goodness \\
\hline
\end{tabular}

\section{Research Instruments}

Statement selection steps that had been used were as follows. 1) Testing the weight of scale of statement value; 2) Testing the distinguishing features of each statement and testing the integrity of each statement with all the statement, and 3) Testing the validity of factors. These were the steps of development of religious commitment instruments: (a) arranging the lattice Religious Commitment Instruments. (Table 3.3) (b). Formulating a statement items (based on the lattice of the instrument table 3.3), and (c). Considering and pitching the statement helped by the experts. The expert were two experts from department of Psychology and Guidance UPI Universitas Pendidikan Indonesia (Indonesian Education University) and an expert who have mastered in Islamic Education from UIN / Universitas Islam Negeri Bandung (State Islam University in Bandung).

a. Testing the weight of scale of statement value (example: Table 3.4), which meet the criteria for scoring the weight scale. The result of this activity can be seen in the appendix

b. Testing the distinguishing features of each statement, and testing the integrity of each statement with all the statement (Edwards 1957: 152). It can be known by calculating the average of difference score of each statement between all instruments. The criteria used were: a statement which has significance t-score between $p=0,05$ until $p=0,10$ deemed to have distinguishing features.

c. Testing the validity of factors. The purpose of this test is to determine whether 
each indicator on each instrument is an integral part of the overall statement on each instrument. This characteristic was tested by calculating correlation between the indicators, and the correlation between each indicator with all indicators. The result test of correlation between indicators in the instrument of religious commitment (attached). This was shown by the quality of relationships which had significance at the 0:01 and 0:05. The result of this test could be concluded that this instrument had adequate internal validity, it means these instruments actually measure what should be measured, for more detail, it can be seen in table 3.5.

\section{The Technique of Data Analysis}

The technique of data analysis that had been used was the technique of statistical analysis descriptive, descriptive analysis technique, $t$ test, and anova test. Descriptive statistical analysis technique was used to analyze data about student religious commitment profile. Descriptive analysis was used to analyze data of students' religious commitment improvement service and the effectiveness of Islamic counselling model implementation process based on field tests. T test was used to analyze: (1) The difference score of the acquisition between student religious commitment experimental groups and control groups after Islamic counselling model had been applied, (2) The difference score of the acquisition of religious commitment between male students and female students who obtain religious commitment improvement service through Islamic counselling Model (3) The difference score of the acquisition of religious commitment between students from state / private high school and state / private religious high school (including religious boarding school). The anova one line test was used to analyze the difference scores based on the acquisition aspects of students' religious commitment (faith, Islam, and Charity) that got from improvement of religious commitment service through Islamic Counselling Model for students.

The normality of distribution test used Kolmogorov-Smirpov test, while the testing of homogeneity performed by using Levene statistics. Implementation of the calculation of statistical analysis was performed by using SPSS V.12 for Windows.

\section{RESULT AND DISCUSSION}

\section{The discussion and research findings were as follows:}

a. The improvement of experimental group's religious commitment: average Increase of control group's religious commitment is $32 \%$ with average score of the post-test is 189.62. More detail can be seen in the chart:

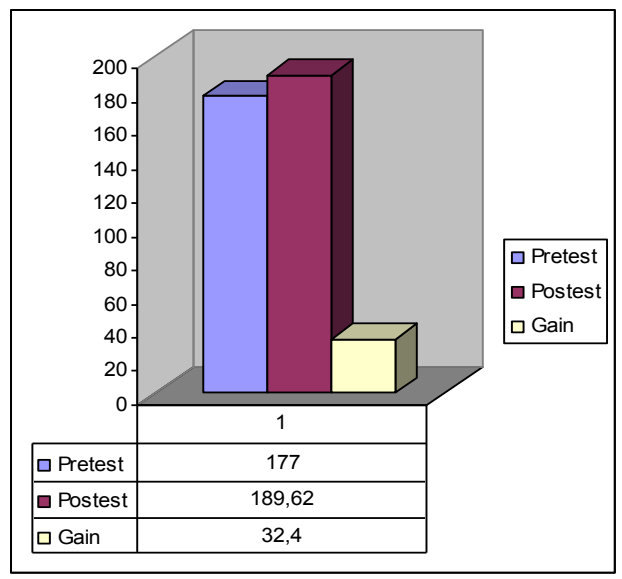


b. The improvement of controlled group's religious commitment: average increase is $17 \%$, with average post-test score is 169,3 :

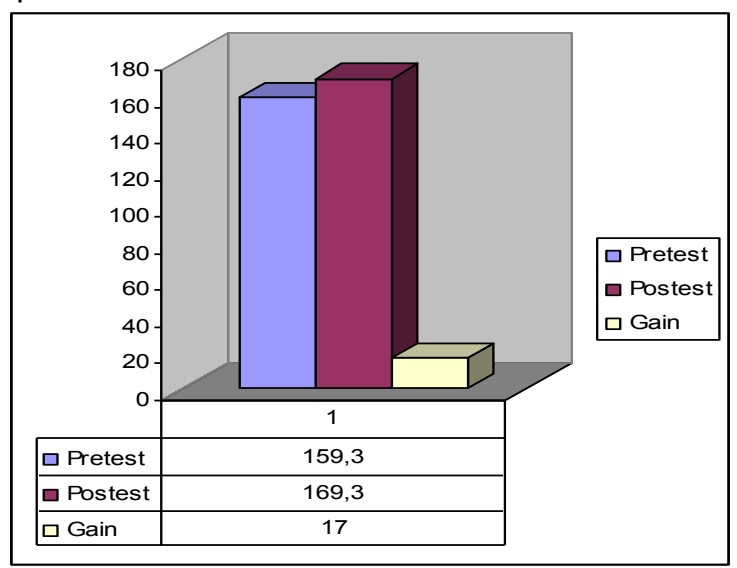

c. The comparison of improvement of religious commitment between experimental group and controlled group: firstly normality test of data improvement had been conducted before doing statistical test to know the comparison of improvement of religious commitment between experimental group and controlled group. As follows:

\begin{tabular}{|l|l|c|c|c|c|c|}
\hline \multirow{2}{*}{} & \multicolumn{3}{|c|}{ Kolmogorov-Smirnov(a) } & \multicolumn{3}{c|}{ Shapiro-Wilk } \\
\cline { 2 - 8 } & Statistic & df & \multicolumn{1}{|c|}{ Sig. } & Statistic & df & Sig. \\
\hline Gain Eksperimen &, 069 & 70 &, $200\left(^{*}\right)$ &, 975 & 70 &, 180 \\
\hline Gain Kontrol &, 081 & 70 &, $200\left(^{*}\right)$ &, 967 & 70 &, 060 \\
\hline
\end{tabular}

Based on the above table it can be concluded that the increase data both students' religious commitments of the experimental group or control group distribute normally. This can be seen from the two tests done of kolmogrove-smirov and Shapiro-Wilk figures indicate significance > 0.05 . For more detail can be seen in the following graph:

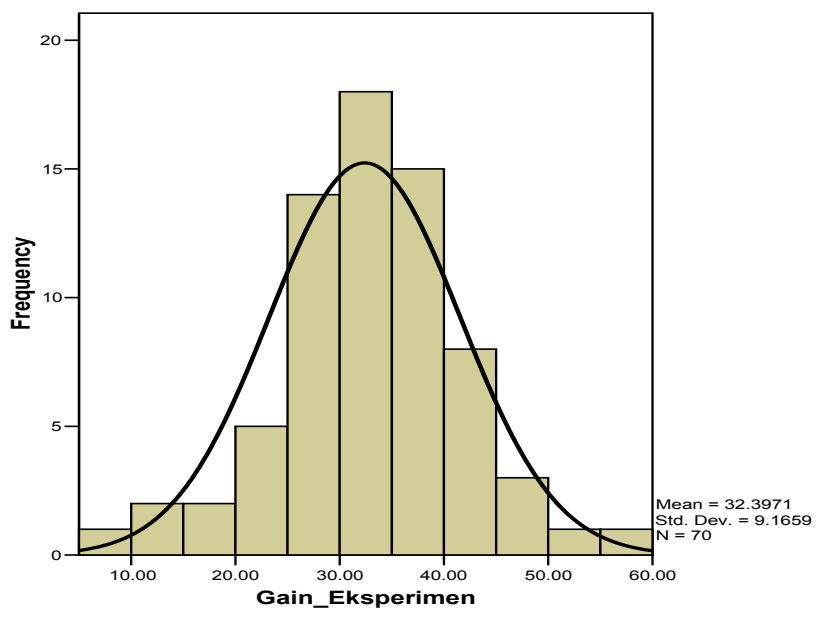

Increased commitment to know the difference between experimental groups and control groups $t$ test for two samples, which saw an average gain of differences within each group. Following results. 


\section{Independent Samples Test}

\begin{tabular}{|c|l|c|c|c|c|c|c|c|c|c|}
\hline \multicolumn{2}{|c|}{ Levene's Test for Equality of Variances } & \multicolumn{6}{|c|}{ t-test for Equality of Means } \\
\hline & & $\mathrm{F}$ & Sig. & $\mathrm{t}$ & $\mathrm{df}$ & $\begin{array}{c}\text { Sig. (2- } \\
\text { tailed) }\end{array}$ & $\begin{array}{c}\text { Mean } \\
\text { Difference }\end{array}$ & $\begin{array}{c}\text { Std. Error } \\
\text { Difference }\end{array}$ & $\begin{array}{c}95 \% \text { Confidence Interval } \\
\text { of the Difference }\end{array}$ \\
\hline Gain & $\begin{array}{l}\text { Equal } \\
\text { variances } \\
\text { assumed }\end{array}$ & 32,574 &, 000 & 4,373 & 138 &, 000 & 14,97719 & 3,42455 & 8,20582 & 21,74856 \\
\cline { 2 - 11 } & $\begin{array}{l}\text { Equal } \\
\text { variances } \\
\text { not } \\
\text { assumed }\end{array}$ & 4,373 & 84,531 &, 000 & 14,97719 & 3,42455 & 8,16772 & 21,78665 \\
\hline
\end{tabular}

The table shows that the $t$ score for the gain of both groups was 4,373 (assuming equal variance) with significance value (probability) was 0.000 . Because the probability was $<0.05$, it can be concluded that the increase in religious commitment of experimental group and control group was different, with an average increase in religious commitment of the experimental group was about $14.97 \%$ higher than average increase in the controlled group.

\section{Discussion of Implementation of Islamic Counselling Model for improving Religious Commitment}

The counselling model on this study was Islamic Counselling Model for improving religious commitment with the strategic mission and operation based on: (1) the value content of Al- Imran in verse of 104 tells amar-ma'ruf Nahi Munkar Concept as a foundation of Islamic counselling mission (2) the value content of An-Nahl in verse of 125 tells Hikmah and M.auizhah as a foundation of strategic operation. The discussion as follows:

\section{a. The value content of Al-Imran in verse of 104}

Amar-ma'ruf Nahi Munkar concept and implementation through Islamic counselling model "And let among you from some people to invite others to the righteousness, order to ma'ruf and prevent to munkar, they are the prosperous people"

In this verse Of 104, Allah order believers to go through the right way and invite people to the righteousness and ma'ruf

According to Sayyid Quthub that there are two things that need to be highlighted in the context of Islamic counselling model relates to the Quran of Ali Imran in verse 104 ( Shihab, 2005), as follows:

First, divine values should not be imposed but persuasively conveyed to students as found in His Word: "Engage to God's way wisely, heartfelt advice and discuss with them with a better way". QS.An-Nahl (16): 125. See ( بالت هى أحس ) (bilati hiya ahsan/with a better ways, not just a "good". In counselling sessions, the counsellor invites students to believe in the right way but not by forcing them, the counsellor gives leeway to students to choose between faith and kufr, but of any choices made have consequences for liquidated. Second, the next things that need to be highlighted is ma'ruf. Ma'ruf has to be ordered and munkar should be prevented by us whether we are the owner of power or not. "Whoever among you saw munkar, then let him change it (make it to ma'ruf) by hand/his power, if he can not afford (no power) to change it, then with his 
tongue/speak, if (with this one) he still can not afford to change it then with his heart, and that's the least of weak faith". Thus the word of the Prophet narrated by several narrators of hadith, among others, Imam Muslim, at-Tirmidhi and Ibn Majah through the Prophet's Companions, Abu Said alKhudri.

Quran as the foundation of the concept of ma'ruf in Islamic counselling model opens widely to accommodate the development of positive values of society. Islamic counselling model concept is media to help individuals (students) to solve the problems of life and a medium of learning the true religious life, the concept also prohibits the imposition of the values of the Quran even though these values are the most basic things like faith and unity of Allah.

Rasulullah said (al-Ghazali, 1996: 80): "Whoever among you saw munkar, then let him change it (make it to ma'ruf) by band/his power, if he cannot afford (no power) to change it, then with his tongue I speak, if (with this one) he still can not afford to change it then with his heart, and that's the least of weak faith". Some ulama (scholars/experts in religion) argue that changing with handdone by the government, orally done by ulama, and with a heart made by a layman, other ulama say that everyone who is able to change munkar, so he has an obligation to change it, as the word of God in the holly Qur'an, Almaidah 02: "and you help each other in doing the virtue and piety, and do not you help each other in doing sin and a violation". (Depag RI, 2004:107)

The concept of ma'ruf in Islamic counselling models opens widely for the development of positive values in society and closes for the development of a negative value. Therefore this model is very suitable to be applied in today as information era which so many offers value. Islamic counselling models trying to hold strong on the rule: keep the good old values and take new better values.

\section{b. Amar ma'ruf concept through Islamic counselling model}

There are four pillars of the concept of amar ma'ruf in Islamic counselling model, namely: (1) a person who rebuke (counselling executor), (2) a person who was rebuked (the person who counselled), (3) deeds be reproved (deeds that counselled), and (4) reprimand (reminiscent in counselling when there is a munkar).

(1) A person who rebuke (counselling executor), The first condition is to be a Muslim who mukallaf; the second is Islam; the third is a man who could behave fairly

(2) A person who is rebuked (the person who counselled), ie: a person who denies the religious teadungs of Islam while claiming Islam.

(3) Deeds be reproved (deeds that counselled), kemunkaran meaning is something that is forbidden to be done according to the Shari'a

(4) Reprimand (reminiscent in counselling when there is a munkar). There are several steps and etiquette in this case:

- Aware of any munkar

- Notification prevent people who should notify the dangers of munkar with good talk

- Prevented by counsel, conducted with softly, not rough and angry

\section{c. Characteristics of people who do amar ma'ruf nahi munkar}

In the application of Islamic counseling model must have at least three characteristics there are knowledgeable, wara': have good attitude (akhlakul karimab) 
Gynecology Value Sura/Chapter An-Nahl/16, verse 125

\section{1) The concept of Islamic Wisdom through Counseling Model}

Invite (mankind, O Muhammad SAW) to the Way of your Lord (i.e. Islam) with wisdom (i.e. with the Divine Revelation and the Qur'an) and fair preaching, and argue with them in a way that is better. Truly, your Lord knows best who has gone astray from His Path, and He is the Best Aware of those who are guided.

That need to be underlined in the Quran sura/chapter An-Nahl/16 verse 125 relating to the concept of Islamic counselling model that is the word "wisdom", which means it is something that when used or paid attention will bring great benefit and convenience, and hinder the loss or great difficulty.

\section{2) The concept of Mau'izhah (preaching) by Islamic Counseling Model}

That need robe underlined in the Quran sura/chapter An-Nahl / 16 verse 125 relating to the concept of mau'izah (preaching) is in submitting suggestions should be in a good way, whereas when jadil (argue) should be a "better way" not only "good". This means that mau'izah (Preaching) there is a good way and there is a bad way.

\section{CONCLUSION}

The study aims to test the effectiveness of Islamic counseling model for helping the students to tight their religious commitment. The religious commitment is covered in three major Islamic teachings: Iman (faith), Islam (surrender to Allah), and Ihsan (state of being observed by Allah). The model of Islamic counseling aims to tight students' religious commitment must to be applied immediately because the preface study reveals some students' religious commitment were not strong enough, their behavior and thinking symptoms tend to not appropriate yet with Islam norm among their association and conception toward the truth of God.

To achieve the aim, the study was carried out with three steps: (1) designing a model of counseling; (2) trying out field study, using pretest-post test control group experimental design with 140 students of Islamic Religion Education, the Faculty of Tarbiyah and Teaching, State Islamic University, Sunan Gunung Djati, Bandung. Of 140 students, 70 students are from the classes: A (32 people), B (38 people), involved in control group and the test; 37 people from class $C$, and 33 students from class $D$ involved in the experiment group, and; (3) designing a final model by revising the model tried-out. The variable involved three major Islamic dimensions: the iman, Islam, and ihsan of the students. The model was designed based on the theory put forward by Musfir bin Said Az-Zahrani, that is, an integrated counseling model. The model combines and employs the ideas from other concepts into a tightly united concept, called Islamic concept.

Upon completing analysis, it was found that the new concept is significantly effective to enhance students' religious commitment. A Model of Islamic Counseling (MIC) is an alternative counseling model that can be employed for teenagers/students to enhance their religious commitment

The study recommends that: (1) MIC can be applied to fifth semester students in the Faculty of Tarbiyah State Islamic University; (2) the application of MIC collaborates with professional and 
proportional elements relevant to the expected aim; (3) the researchers studying the same materials use the appropriate method appropriate to individual characteristics referring to Islamic norms kaffah (integrally). 


\section{References}

Abdullah, Taufik dan Karim, M Rusli. (1989). Metodologi Penelitian Agama.Yogyakarta: Tiara Wacana.

Abdulrahim, Imaduddin. (1979). Kuliah Tauhid. Bandung: Pustaka-Perpustakaan Salman ITB.

Al-Ghazali, Imam. (1995). Mukhtashar Ihya' Ulumuddin/Ringkasan Ihya' Ulumuddin. Penerjemah: Zaid Husein Al Hamid. Jakarta: Pustaka Amani.

(1995). Minhajul 'Abidin/Petunjuk Ahli Ibadah. Penerjemah: Abul Hiyadh. Surabaya: Mutiara IImu.

(1996).Mukaasyafatul Qulub/Menyibak Dunia Metafisik (Ketajaman Mata Hati). Penerjemah:Achmad Sunarto. Bandung: Husaini.

Al-Maraghi, Ahmad Mushthofa. (1974). Tafsir Al-Maraghi. Libanon-Beirut: Dar al-Ma'rifah (1984). Tafsir Al-Maraghi. Alih Bahasa: Bahrun Abu Bakar. Semarang: CV. Toha Putra.

Al-Maududi, Abul A'la. (1985). Prinsip-prinsip Islam. Jakarta: Lembaga Pengajaran Bahasa Arab Saudi Arabia.

Al-Quran dan Terjemahnya. (1971). Saudi Arabia: Khadim Al-Haramain

An-Najjar, Amir. (1986). Al-Khawariz, Aqidatan, Fikratan wa Falsafatan. Cetakan ke-1.Beirut: Alamul-Kutub.

An-Najjar, Amir. (1992). Aqidah, Pemikiran, \& Filsafat Khawarij. Penerjemah: Kathur Suhardi. Solo: CV. Pustaka Mantiq.

Ancok, Djalaludin. (1994). Psikologi Islami (Solusi Islam atas Problem-problem Psikologi). Yogyakarta: Pustaka Pelajar

Anshari, Endang Saifuddin. (1983). Wawasan Islam - Pokok pokok Pikiran tentang Islam dan Umatnya.Bandung: Pustaka Salman ITB.

Archer,S.L (editor). (1994). Interventions for Adolescent Identity Development. London: Age.

Arikunto. (1998). Prosedur Penelitian suatu Pendekatan Praktek. Jakarta: Rineka Cipta.

Azwar, Saifuddin. (2003). Sikap Manusia, Teori, dan Pengukurannya. Yogya: Pustaka Pelajar (2003). Penyusunan Skala Psikologi. Yogya: Pustaka Pelajar

Az-Zahrani, Musfir bin Said. (2005). Konseling Terapi. Jakarta: Gema Insani.

Baidan, Nasruddin. (2000). Metode Penafsiran Al-Quran. Yogyakarta: Pustaka Pelajar (2002). Metode Penafsiran Al-Quran. Yogyakarta: Pustaka Pelajar 
Best, John W. (1977). Research in Education. India: Prentice-Hall.

Berk. (1986). Adolescence Developmental. Tokyo: International Student Edition, Mc. Graw-Hill Kugakusha Ltd.

Bisri, Cik Hasan. (1999). Agenda Pengembangan Pendidikan Tinggi Agama Islam. Jakarta: Logos Wacana IImu.

Blocher, Donald, H. (1974). Developmental Counseling.New York-USA: JohnWiley \& Sons.

Borg, W. R. \& Gall, M. D. (1983). Educational Research: An Introduction. New York: Longman.

Brammer L.M./Shostrom E.L. (1982). Therapeutic Psychology (Foundamental of Counseling and Psychoterapy).

Brayfield, Arthur H. (1950). Reading in Modern Methods of Counseling. New York: Appleton-CenturyCrofts.

Campbell, D. T. \& Stanley, J. C. (1966). Experimental and Quasi-Experimental Designs for Research. Boston: Houghton Mifflin Company.

Choliq. (2007). Perspektif Islam tentang Bimbingan dan Konseling. Tersedia: http://www.unissula.ac.id//show.php?buka=beritautama\&id=134. (06April 2008)

Corey, G. (1991). Theory and Practice of Group Counseling. Pacific Grove. California: Brooks/Cole Publishing Company.

(2003). Teori dan Praktek Konseling dan Psikoterapi. Alih bahasa oleh E. Koswara. Bandung: PT Refika Aditama.

Cozby, S.R. (1989). Methods in Behavioral Research. Third edition. Hayfield Publishing Company.

Calhoun, James F. and Acoccella, Joan Ross (1995). Psychology of Adjustment and Human Relationships. third edition, terjemahan Prof Dr. R. S. Satminok.o, edisi pertama, Semarang: IKIP Semarang Press.

Crapps, Robert W. Gaya Hidup Beragama Authoritas yang Sedang Menjadi Mistik. Yogyakarta: Kanisius.

Dahlan, M.D. (1987). Dasar-dasar Konseptual Penanganan masalah-masalah Bimbingan dan Konseling Islami di Bidang Pendidikan (Suatu Alternatif Pendekatan). Makalah pada Seminar dan Loka Karya Bimbingan dan Konseling Islami II di Yogyakarta 15-17 Oktober 1987.

(1988). Posisi Bimbingan dan Penyuluhan Pendidikan dalam Kerangka Ilmu Pendidikan (Pidato Pengukuhan Jabatan Guru Besar dalam IImu Pendidikan pada FIP

Daradjat, Zakiah. (1973). Peranan Agama dalam Kesehatan Mental.Jakarta: Gunung Agung 
De Cecco, Jhon P. \& Crawford, William. (1977). The Psychology of Learning and Intruction. New Delhi: Prentice-Hall of India Private Limited.

Depag RI. (2004). Al-Qur'an dan Terjemahnya. Bandung: CV. Penerbit J-ART

Edward, A.L. (1957). Techniques of Attitude Scale Construction. New York: Appleton- Century Crofts.

Fahmy, Moustafa. (1963). Aishihah Annafsiyah fil Usrah wal Mujtama. Cairo: Darul El Tsaqafah.

Faridl, Miftah. (2006). Pokok-pokok Ajaran Islam. Bandung: Pustaka.

Gay, L.R. (1987). Educational Research. Third Edition. Toronto: Merril Publishing Company

Gazda, G.M. (1989). Group Counseling: A Developmental Approach.Boston: Allyn \& Bacon.

Gerdes, H. \& Mallinckrodt, B. (1994). Emotional, Social, and Academic Adjustment of College Students: A Longitudinal Study of Retention. Journal of Counseling and Development, 72, 281-288.

Glock, Charles Y dan Strak, Rodney. (1965). Religion and Society in Tension. Chicago: Rand Mc. Nally \& Company, University of California Barkeley.

Hamidy, Muchlis. (1998). Manusia dalam Perspektif Al-Quran. Surakarta: Purimedia

Hana, Attia Mahmoud. (1959). Attaujih Attarbawi wal Mihani. Cairo: Maktabah Annahdhah Almishrijah.

Hanifah, Abu. (1983). Hajatul Insan Ilad Din (Perlunya Manusia beragama). Garut: Pesantren "Darul Arqom".

Hadi, Sam Qomarul. (1981). Identitas Mukmin. Surakarta-Majelis Pengajian Islam Gading Wetan 132: PT. Al-Ma'arif.

Hamka. (1987). Tafsir Al-Azhar. Jakarta: Pustaka Panjimas

Heppner, P.P. et al. (1992). Research Design in Counseling. Pacific Grove. California: Brooks/Cole Publishing Company.

James, William. Psychoanalysis and Religum.[Online]. Tersedia: http:/ /www.ed.uiuc.edu/EPS/PESYearbook/1998/Thompson. hotml

Jacobs, Ed E., Harvill R.L., \& Masson R.L. (1994). Group Counseling: Strategie and Skills (second Edition). California: Brooks/Cole Publishing Company.

Jaiz, Hartono Ahmad. (2004). Menangkal Bahaya JIL (Jaringan Islam Liberal) dan FLA (Fikih Lintas Agama). Jakarta Timur: Pustaka Al-Kautsar - Penerbit Buku Islam Utama. (2005). Ada Pemurtadan di IAIN. Jakarta Timur: Pustaka Al-Kautsar - Penerbit Buku Islam Utama. 
Juckman, B.W.(1978). Conducting Educational Research. New York: Harcourt Brace Javanovich, Inc.

Kaplan, Robert M dan Sacuzzo, Dennis P. (1992). Psychological Testing Principles Application and Issue. California: Broks/Cole Publishing Company.

Kim, B. S. K. \& Lyons, H. Z. (2003). Experinetial Activities and Multicultural Counseling Competence Training. Journal of Counseling and Development, 81, 400-408.

Krathwohl, David R. (1993). Methods of Educational and Social Science Research. An Integrated Approach. New York: Longman.

Lari. M. Sayyid. (1993). Membangun Kembali Moral Generasi Muda. Bandung: Pustaka Hidayah.

Larson,D. (1984). Teaching Psychological Skills: Models for Giving Psychology Eway. Monterey, California Brooks/Cole Publishing Company.

Lazarus, R.S. \& Folkman, S. (1964). Stress, Appraisal and Coping. New York: Springer Publishing Company.

Marcia, JE. (1993). Ego Identity A Handbook for Psychological Research.New York: Springer-Verlag.

Madjid, Nurcholis. (1992). Islam Doktrin dan Peradaban (Sebuah Telaah Kritis tentang Masalah Keimanan, Kemanusiaan, dan Kemoderenan). Jakarta: Yayasan Wakaf Paramadina.

Mahoney, J.L., Cairns, B.D. \& Fanner, T.W. (2003). Promoting Interper sonal Competence and Educational Success through Extracurricular Activity Participation. Journal of Educational Psychology 95 (2): 409-418.

Marton. (1996). Educational Research. Third Edition. Toronto: Merril Publishing Company.

Montgomery, D.C. (1984). Design and Analysis of Experiments, Edisi ke-2. Singapore: John Wiley \& Sons, Inc.

Mueller, Danniel J. (1990).Measuring Social Attitudes. A Handbook for Researchers and Practitioners. New York: Published by Teachers College Press.

Mubarok, Achmad. (2006). Pengembangan Healing dan Konseling Berbasis Psikologi Islam. Tersedia: http://mubarok-institute.blogspot.com/2006/07/pengembangan-healing-dankonseling.html. (06April 2008)

Najati, M. Utsman. (1985). Al-Quran dan IImu Jiwa. Bandung: Pustaka

Nelson-Jones, Richard. (1995). Counselling and Personality, Theory and practice. St. Leonards, NSW, Australia: Allen and Unwin Ptd. (1995a). Human Relationship Skills. Second Edition. Marricville, NSW.: Harcourt Brace \& Company Australia.

(1997). Practical Counselling \& Helping Skills. Texts and Exercises for the Lifeskills Counselling Model. Fourth Edition. London: British Library Cataloging-in Publication Data. 
Nurihsan, Juntika. (2006). Akhlak Mulia dalam Perspektif Bimbingan dan Konseling Islami. Bandung: Rizki Press.

O'Donohue, William \& Krasner, Leonard (1995). Handbook of Psychological Skills Training. Clinical Techniques and Aplications. Needham Heights, Massachusetts: Allyn and Bacon.

Qardhawi, Yusuf. (1983). Iman dan Kehidupan. Solo: Pustaka Amanah.

Qudamah, Ibnu. (1997). Minhajul Qoshidin/Jalan Orang-orang yang Mendapat Petunjuk. Penerjemah: Kathur Suhardi. Jakarta Timur: Pustaka Al-Kautsar.

Qosim, Abil Mahmud bin Umar Al-Zamakh Syari. Tafsir "Al-Kasyaf 'an Haqaiq al-Tanzil wa 'uyun alAqowil fi Wujuh al-Ta'wil. Libanon- Bairut: Darul al-Ma'rifah.

Rathomy, Moh. Abdai. (1983). Bimbingan untuk Mencapai Tingkat Mu'min. Bandung: c.v. Diponegoro

Robinson, Floyd F. \& Hardt, Dan A. (1992). Effects of Cognitive and Behavioral Structure and Discussion of Corrective Feedbeck Outcames of Counseling Group Development. Journal of Counseling Psychology, 39: 473-481.

Romiszowski, A.J. (1986). Producing Intructional Systems. London: Kogan Page.

Sandoval, Jonathan. (1993). The History of Interventions in - School Psychology. Vol. 31, p. 195217.

Sarlito, W. (1991). Psikologi Remaja. Jakarta: Rineka Cipta.

Shaver, Kelly G. (1977). Principles of Social Psychology. Cambridge, Massachusetts: Withrop Publishers, Inc.

Shihab, M. Quraish. (1996). Wawasan Al-Quran-Tafsir Maudhu'i atas Pelbagai Persoalan Umat. Bandung: Mizan.

(2005). Tafsir Al-Misbah: Pesan, Kesan, dan Keserasian al-Quran. Cetakan ke-4. Jakarta: Lentera Hati.

Sugiyono. (2003). Statistika untuk Penelitian. Bandung: CV Alfabeta.

(2004). Metode Penelitian Administrasi. Bandung: CV Alfabeta.

Suherman AS, Uman. (2006). Model Pendekatan Konseling Kecakapan Hidup Berbasis al-Quran dan Hadits untuk Mengembangkan Keterampilan Hubungan Sosial (Studi Deskriptif Analitik tentang Upaya Pengembangan Keterampilan Hubungan Sosial Santri Pesantren Islam 99 Rancabogo Kabupaten Garut). Disertasi. Bandung: PPs UPI

Sukartini, SP. (2001). Model Konseling Keterampilan Hidup untuk Mengembangkan Karakteristik Pribadi yang Tegar. Disertasi. Bandung: PPS-UPI.

Supriatna, Mamat dan Nurihsan, Achmad Juntika. (2005). Pendidikan dan konseling di Era Global 
dalam Perspektif Prof. DR. M. Djawad Dahlan. Bandung: Rizqi press.

Suriasumantri, Yuyun S. (1987). Filsafat IImu sebuah Pengantar Populer. Jakarta: Pustaka Sinar Harapan.

Sutoyo, Anwar. (2006). Pengembangan Fitrah Manusia melalui Pendidikan Berbasis Konseling dalam Perspektif Al-Quran menuju Pribadi Kaffah (Uji Coba Peningkatan Religiusitas Mahasiswa Jurusan Bimbingan dan Konseling Smt. Genap tahun 2005 dalam Upaya Menyusun Model Konseling Islami). Disertasi. Bandung: PPs-UPI.

Syarifuddin, Cecep dkk. Mengukur Sikap-Sikap Sosial. Bandung: Fisip Press-Unpas.

Tim Penelitian dan Pengembangan Wahana Komputer. (2003). Pengolahan Data Statistik dengan SPSS 11.5. Jakarta: Salemba Infotek.

Musnawar, Tohari dkk. (1992). Bimbingan dan Konseling Islami. Yogyakarta: UII Press.

UIN Bandung. (2005). Transformasi IAIN menjadi UIN dalam Upaya Memadukan Ayat-ayat Quraniyyah dan Kauniyyah.Disampaikan dalam Pidato Rektor pada acara Dies Natalis ke-37. Bandung

Wulff, David M. (1997). Psychology of Religion Classic and Contemporary. Second Edition. New York: John Wiley \& Sons. INC.

Yusuf L.N., Syamsu. (2007). Konseling Spiritual Teistik (Proses Pencerahan Diri dalam Membangun Kehidupan Bersama yang Bermakna). Makalah pada Pidato Pengukuhan Guru Besar Tetap dalam IImu Bimbingan dan Konseling. Bandung: UPI.

Zaini, Syahminan. (1980). Mengenal Manusia lewat Al-Quran. Surabaya: Bina IImu 